\title{
Assessment of Functional Lipid Constituents of Red (Aristaeomorpha foliacea) and Pink (Parapenaeus longirostris) Shrimps
}

\author{
Georgia Soultani ${ }^{1}$, Irini F Strati ${ }^{2}$, Panagiotis Zoumpoulakis ${ }^{3}$, Sofia Miniadis-Meimaroglou ${ }^{1}$ and Vassilia J Sinanoglou ${ }^{* *}$
}

${ }^{1}$ Food Chemistry Laboratory, Department of Chemistry, National and Kapodistrian University of Athens, Panepistimiopolis Zographou, Athens, Greece ${ }^{2}$ Laboratory of Chemistry, Analysis and Design of Food Processes, Instrumental Food Analysis, Department of Food Technology, Technological Educational Institute of Athens, Ag-Spyridonos, Egaleo, Greece

${ }^{3}$ Institute of Biology, Medicinal Chemistry and Biotechnology, National Hellenic Research Foundation, 48, Vas Constantinou Ave., Athens, Greece

\begin{abstract}
Red shrimp is a unique source of nutraceuticals including omega- 3 fatty acids and carotenoids. The presence of nutraceuticals depends on the quality and the consumption of phytoplankton and zooplankton. In the Mediterranean Sea, red shrimp (Aristaeomorpha foliacea) and pink shrimp (Parapenaeus longirostris) are two of the most prevalent species which are assessed in this study in respect to essential nutrients, fatty acids and carotenoids. Results indicated that the $\omega-3 / \omega-6$ polyunsaturated fatty acids ratio in $A$. foliacea and $P$. longirostris muscle lipids exhibited considerable values $(>2.9)$, indicating a healthy diet. Regarding carotenoids, astaxanthin was the most prevalent, already correlated with antioxidant support to nervous and musculoskeletal systems, followed by lutein, canthaxanthin, zeaxanthin, $\alpha$ - and $\beta$-cryptoxanthin. Phosphatidylcholine and polyunsaturated fatty acids predominated in shrimps' muscle lipids, while monounsaturated fatty acids in cephalothorax. Palmitic, oleic acids

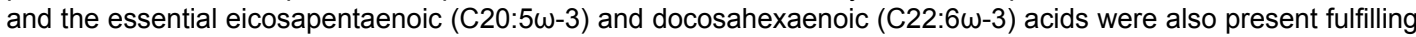
the high nutritional profile of both shrimps.
\end{abstract}

Keywords: Carotenoids; Cephalothorax; Fatty acids; Lipids; Muscle; Shrimp

\section{Introduction}

Shrimp represents one of the most widely consumed species of the Mediterranean and comprise an important source of nutrients in the human diet [1]. Aristaeomorpha foliacea (Risso 1827, commercial name: giant red shrimp) of the Aristeidae family is widely distributed in the eastern and western Atlantic, the western Pacific, the Indian Ocean and the Mediterranean Sea and located at depths ranging from $250 \mathrm{~m}$ to $1300 \mathrm{~m}$ with maximum abundance found between $500 \mathrm{~m}$ and $700 \mathrm{~m} \mathrm{[2].} \mathrm{Parapenaeus} \mathrm{longirostris} \mathrm{(Lucas} \mathrm{1846,} \mathrm{deep} \mathrm{seawater}$ rose shrimp) of the Penaeidae family lives at depths ranging from 20 $\mathrm{m}$ to $700 \mathrm{~m}$. Parapenaeus longirostris is commonly found in all over the Mediterranean and the Atlantic, as well as, in the West (from Massachusetts to French Guiana) and the East (from Portugal to Angola) [2]. Aristaeomorpha foliacea is distinguished by an intense uniform red coloring and it is considered large-sized, with ranging on average from $13 \mathrm{~cm}$ to $20 \mathrm{~cm}$, while $P$. longirostris has a rose color and its length ranges from 8 to $16 \mathrm{~cm}$ [2]. The color of shrimp is due to its carotenoid content, which provides the typical red-orange tissue pigmentation and varies according to its native habitat [1]. The differences between the shrimp species seem to be highly dependent on the type and variability of the oceanography of the sea and the trophic characteristics in which these species spend most of their adult life [2].

Both types are active predators and scavengers. Furthermore, the above mentioned shrimps, are some of the most commercially important exploited crustaceans by trawlers in Mediterranean deepwater fisheries and the most economically and ecologically important crustacean resource in the Mediterranean basin [3]. They are available on the market fresh, refrigerated or frozen, while $P$. longirostris is also available through aquaculture. Their meat is considered to be highly nutritious and constitutes like many crustaceans, part of the Mediterranean diet, which is beneficial for different consumer groups [4], while for the Mediterranean countries, the cephalothorax (head and hepatopancreas) of shrimps is a distinctive delicacy, rich in substances essential for the human diet.
Shrimps are a widely distributed commercial catch in the Mediterranean Sea, comprising one of the main fishery food resources and a high proportion of fishery products consumed; therefore, it is of particular importance to evaluate their nutritional value. Moreover, the differentiation regarding the nutritive data of shrimp muscle (edible part) and cephalothorax (by-products) lipids has not been well-documented. An in-depth analysis was necessary in order to establish whether the above characteristics were reflected in proximate composition and lipid profile of shrimps, both qualitatively and quantitatively. Therefore, the aim of the present study was to assess the bioactive lipid constituents' profile of muscle and cephalothorax of the deep seawater giant red shrimp Aristaeomorpha foliacea and the rose shrimp Parapenaeus longirostris. The ultimate goal was to estimate the nutritional value of muscle as well as to attain the exploitation of cephalothorax, to produce bioactive compounds.

\section{Materials and Methods}

\section{Chemicals, standards and solvents}

The lipid standards used were: cholesteryloleate, cholesterol, tristearoyl-glycerol, lauric acid, oleic acid, linoleic acid, 1,2-distearoylglycerol, 1-monostearoyl-rac-glycerol, phosphatidylcholine, phospha-

*Corresponding author: Vassilia J Sinanoglou, Laboratory of Chemistry, Analysis and Design of Food Processes, Instrumental Food Analysis, Department of Food Technology, Technological Educational Institute of Athens, Ag-Spyridonos 12210, Egaleo, Greece, Tel +30210 5385523; E-mail: v_sinanoglou@yahoo.gr, vsina@teiath.gr

Received May 27, 2016; Accepted October 26, 2016; Published October 28, 2016

Citation: Soultani G, Strati IF, Zoumpoulakis P, Meimaroglou SM, Sinanoglou VJ (2016) Assessment of Functional Lipid Constituents of Red (Aristaeomorpha foliacea) and Pink (Parapenaeus longirostris) Shrimps. J Aquac Res Development 7: 452. doi: 10.4172/2155-9546.1000452

Copyright: (c) 2016 Soultani G, et al. This is an open-access article distributed under the terms of the Creative Commons Attribution License, which permits unrestricted use, distribution, and reproduction in any medium, provided the original author and source are credited. 
tidylethanolamine, lyso-phosphatidylcholine, lyso-phosphatidylethanolamine, phosphatidylinositol, phosphatidylserine and sphingomyelin standards of the Sigma Chemical Co (Sigma-Aldrich Company, Dorset, Great Britain and St. Louis, MO). Fatty acid methyl esters used as GC-FID standard mixtures were: Supelco TM 37 Component FAME Mix C4-C24, $100 \mathrm{mg}$ and Supelco PUFA No.1, Marine Source, $100 \mathrm{mg}$. All-trans carotenoid standards (lycopene, $\beta$-carotene, lutein, zeaxanthin, canthaxanthin, $\alpha$ - and $\beta$-cryptoxanthin and astaxanthin) were purchased from Sigma Chemical Co (Sigma-Aldrich Company, St. Louis, MO, USA). All solvents used for sample preparation and extraction were of analytical grade and the solvents used for GC-FID, Iatroscan TLC-FID and HPLC-DAD analyses were of HPLC grade from Merck (Darmstadt, Germany). Double distilled water was used throughout this work. All reagents used were of analytical grade and they were purchased from Mallinckrodt Chemical Works (St. Louis, MO) and from Sigma Chemical Co (Sigma-Aldrich Company, UK).

\section{Sampling}

Specimens of deep seawater shrimps, A. foliacea and P. longirostris, were studied. The shrimps were caught during spring time (MarchMay) from Ionian Sea area and were purchased from a commercial fish market, with two repetitions in 2014 and 2015. The specimens (batches of $30 \mathrm{~kg}$, per species and per year) were transported to the laboratory where they were washed with cold distilled water; weighed (46.48 $\pm 5.55 \mathrm{~g}$ and $9.44 \pm 3.37 \mathrm{~g}$, respectively) and the average length was measured $(18.95 \pm 1.38 \mathrm{~cm}$ and $12.07 \pm 1.31 \mathrm{~cm}$, respectively). Then, the specimens were divided in three groups according to their weight, they were dissected; muscles and cephalothoraxes were weighed and then separately homogenized in a blender for the determination of proximate, lipids and fatty acid composition. The analytical parameters were determined at least in triplicate for each group $(n=6$ samples per species and tissue, for the two repetitions).

\section{Proximate analysis}

Moisture content was determined by oven drying at $105^{\circ} \mathrm{C} \pm 2^{\circ} \mathrm{C}$ to reach constant weight, crude protein by Kjeldahl procedure and ash by heating in a muffle furnace at $550^{\circ} \mathrm{C}$ to constant weight [5]. Homogenized muscle and cephalothorax total lipids of shrimps were extracted (separately), according to the Bligh and Dyer method [6]. After phase equilibration, the lower chloroform layer (TL) was removed and dried in a rotary vacuum evaporator at $32^{\circ} \mathrm{C}$. The extracted lipids were weighed in order to determine the TL content, then redissolved in chloroform/methanol $(9: 1, \mathrm{v} / \mathrm{v})$ and finally stored at $0^{\circ} \mathrm{C}$ until further use. To prevent oxidation t-butyl-hydroquinone was added to all samples during preparation.

\section{Iatroscan TLC-FID analysis of neutral and polar lipids}

Lipid classes were separated on silicic acid-coated quartz rods, chromarods (Type SIII, $5 \mathrm{~mm}$ silica gel-coated quartz rod, Iatron Labs, Tokyo, Japan) and they were quantified using a thin layer chromatography-flame ionization detection system. Iatroscan TLCFID analysis was performed by an Iatroscan thin-layer chromatograph (Model MK-6 TLC/FID - FPD Analyser Iatron Laboratories, Tokyo, Japan) equipped with a flame ionization detector. Individual lipid classes were quantified as described previously by Sinanoglou et al. [7].

\section{Gas chromatography analysis of fatty acid methyl esters}

Fatty acid methyl esters (FAME) of total lipids (TL) were prepared according to the procedure described by Sinanoglou et al. Both quantitative and qualitative analysis were performed on an Agilent
6890 Series Gas Chromatograph (Agilent Technologies, Palo Alto, CA) equipped with a flame ionization detector, as described by Sinanoglou et al. [7]. DB-23 capillary column $(60 \mathrm{~m} \times 0.25 \mathrm{~mm}$ i.d. $0.15 \mu \mathrm{m}$ film $)$ (50\%-cyanopropyl-methylpolysiloxane) (Agilent Technologies, USA) was used. The individual FAME were identified by comparing their retention times with those of the authentic standard mixtures. The relative content of fatty acids in the sample was determined according to Sinanoglou et al. [7].

\section{Indices calculations}

The ratio between hypocholesterolaemic and hypercholesterolaemic fatty acids $(\mathrm{h} / \mathrm{H})$ was calculated according to the formulas suggested by Santos-Silva et al. [8]:

$(C 18: 1 \omega 9+C 18: 2 \omega 6+C 18: 3 \omega 3+C 20: 4 \omega 6+$

$C 20: 5 \omega 3+C 22: 5 \omega 3+C 22: 6 \omega 3) /(C 14: 0+C 16: 0)$

The atherogenic index (AI) and thrombogenic index (TI) were calculated according to the formulas proposed by Ulbricht and Southgate [9]:

$$
\begin{aligned}
& A I=[12: 0+(4 \times 14: 0)+16: 0] / \text { and } \\
& (\omega-3 P U F A+\omega-6 P U F A+M U F A) \\
& T I=(14: 0+16: 0+18: 0) /(0.5 M U F A+ \\
& 0.5 \omega-6 P U F A+3 \omega-3 P U F A+\omega-3 P U F A / \omega-6 \text { PUFA })
\end{aligned}
$$

The cholesterol index (CI) was calculated according to the Zilversmit [10] formula:

$$
\begin{aligned}
& C I=1.01(\mathrm{~g} \text { of SFA } / 100 \mathrm{~g} \text { of fresh matter }-0.5 \times \mathrm{g} \text { of PUFA } / 100 \mathrm{~g} \text { of fresh matter })+ \\
& (0.06 \times \mathrm{mg} \text { of cholesterol } / 100 \text { goffreshmatter }
\end{aligned}
$$

While the cholesterol-saturated fat index (CSI) was calculated according to the formula proposed by Connor et al. [11]:

$$
\begin{aligned}
& C S I=(1.01 \times g \text { of } S F A / 100 g \text { of fresh matter })+ \\
& (0.05 \times m g \text { of cholesterol } / 100 \mathrm{~g} \text { of fresh matter }) .
\end{aligned}
$$

\section{Carotenoid analysis}

For the identification of the different carotenoids, total lipids from shrimp muscle and cephalothorax were further analyzed by HPLCphotodiode array detection. Before being injected, lipid samples were dried under nitrogen gas and dissolved in acetone:hexane $(2: 3$, by volume). Afterwards, samples were filtered through a $0.45 \mu \mathrm{m}$ membrane filter to remove particulate residues. Twenty microliters of solution were injected for the HPLC analysis. The identification and quantification of carotenoids was performed according to Strati et al. [12].

\section{Statistical analysis}

The measurements of all the groups were carried out (at least) in triplicate; the values were averaged and reported along with their standard deviation (S.D). All data concerning proximate, lipid, fatty acid and carotenoid composition were analyzed with One-Way ANOVA Post Hoc Tests, and pairwise multiple comparisons were conducted with the Tukey's test. Probabilities lower than 0.05 were considered as statistically significant $(\mathrm{P}<0.05)$. All statistical calculations were performed with the SPSS package (IBM SPSS Statistics, version 19.0, Chicago, IL, USA) statistical software for Windows.

\section{Results and Discussion}

\section{Proximate composition}

The proximate chemical composition of red shrimp (A. foliacea) 
and rose shrimp (P. longirostris) muscle and cephalothorax is shown in Table 1. Total lipid and ash contents of both shrimp cephalothorax were significantly $(\mathrm{P}<0.05)$ higher, while moisture content was significantly lower, than of respective muscle. Furthermore, total lipid content in the cephalothorax of $A$. foliacea was found to be significantly higher $(\mathrm{P}<0.05)$ than total lipid and ash content of the P. longirostris cephalothorax (Table 1). Protein was found to be the major constituent in the muscle of both shrimps, which is critical for muscle growth and normal function.

These results were significantly different compared to those of Penaeus kerathurus (pink shrimp) reported in an earlier study from this laboratory [13]. The total lipid content of $P$. kerathurus muscle and cephalothorax was $1.30 \% \pm 0.06 \%$ and $2.40 \% \pm 0.05 \%$, respectively [13]. The results of this study, regarding fat content, were similar with those reported by Manjabhat et al. [14] for the edible part of S. indica and A. alcocki (0.94\% and 2.7\%, respectively) and for the cephalothorax (1.1\% and $8.1 \%$, respectively), by Turan et al. [15] for brown shrimp (Crangon crangon) muscle and by Li et al. [16] for 2 freshwater and 5 marine shrimps from China, higher than those reported by Rosa and Nunes [17] for red shrimp (Aristeus antennatus) and Norway lobster (Nephrops norvegicus) and lower than those reported by Sriket et al. [18] for Penaeus monodon and Penaeus vannamei muscle and by Yerlikaya et al. [4] for Aristeus antennatus, Aristeomorpha foliacea, Plesionica martia, Parapenaeus longirostris, and Plesionica edwardsi muscle from deep water; and Metapenaeus monoceros, Penaeus semisulcatus, Penaeus kerathurus, and Penaeus japonicus muscle from shallow water.

Other shrimp species reported, such as Solonocera indica and Aristeus alcocki from India, were found to have higher moisture content in muscle $(83.6 \%$ and $81.0 \%$, respectively) and in cephalothorax ( $80.4 \%$ and $77.2 \%$, respectively) than the shrimp species studied, but lower or equal ash content $(0.68 \%$ and $6.5 \%$ for $S$. indica muscle and cephalothorax respectively, and $0.65 \%$ and $4.0 \%$ for $A$. alcocki muscle and cephalothorax, respectively) [14]. Furthermore, our results regarding the moisture and ash content for the examined shrimp muscles were comparable with those reported by Sriket et al. [18] for black tiger shrimp (Penaeus monodon) ( $80.47 \%$ and $0.95 \%$ respectively), by Rosa and Nunes [17] for red shrimp (Aristeus antennatus) (73.6\% to $74.5 \%$ and $2.0 \%$ respectively) and Norway lobster (Nephrops norvegicus) ( $74.7 \%$ to $75.2 \%$ and $2.0 \%$ to $2.1 \%$ respectively) and by Sriket et al. [18] for white shrimp (Penaeus vannamei) (77.21\% and $1.47 \%$ respectively). Concerning protein content, $A$. foliacea and $P$. longirostris muscle had similar protein content with those reported by Sriket et al. [18] for P. monodon and P. vannamei and by Turan et al. [15] for brown shrimp (Crangon crangon) and lower than those reported by Rosa and Nunes [17] for red shrimp (Aristeus antennatus) and Norway lobster (Nephrops norvegicus).

Differences in proximate composition might result in differences in nutritional value, sensory qualities and shelf-life of the shrimps. Proximate compositions in shrimp muscles are governed by many factors, including species, growth stage, sex, feed and season [18].

\section{Neutral and polar lipids}

The lipid classes' profile of red shrimp (A. foliacea) and rose shrimp (P. longirostris) muscle and cephalothorax is presented in Table 2. Neutral lipids (NL) of the studied shrimp muscle mainly consisted of cholesterol, followed by triglycerides (TG) (Table 2), and while in the cephalothorax TG were the major NL as they constitute the main energy storage of the deep water shrimp species [19]. The detection of free fatty acids and diglycerides only in A. foliacea, muscle and cephalothorax suggested that lipid from red shrimp may be more susceptible to hydrolysis.

Polar lipids (PL) were the predominant lipids (>87\%) in both shrimp muscle. Phosphatidylcholine (PC) and phosphatidylethanolamine (PE) were the major PL accounting for $\sim 80 \%$ of total lipids and in a ratio of about $3: 1(\mathrm{w} / \mathrm{w})$, whereas phosphatidylserine (PS), phosphatidylinositol (PI) and sphingomyelin (SM) were detected as minors PL. Phosphatidylinositol (PI) detected in the muscles is a phospholipid signal molecule that may be important in marine organisms. It is thought that the precursors to prostaglandins in marine fish are eicosapentaenoic (20:5 $\omega-3)$ and docosahexaenoic $(22: 6 \omega-3)$ acids derived from phosphatidylinositol [19]. The PL proportion in total lipids of both shrimp cephalothorax was significant lower $(\mathrm{P}<0.05)$ to that found in the muscle and $\mathrm{PC}$ was by far the largest component followed by PE.

On a weight basis, significant differences $(\mathrm{P}<0.05)$ in the neutral and polar lipids content were found between tissues and species (data calculated from Tables 1 and 2). Evaluated per $100 \mathrm{~g}$ of wet weight, the $A$. foliacea's muscle contained $452.95 \pm 34.18 \mathrm{mg}$ of PC, $140.94 \pm$ $9.94 \mathrm{mg}$ of PE, $56.12 \pm 3.86 \mathrm{mg}$ of cholesterol, $24.35 \pm 1.44 \mathrm{mg}$ of TG and $24.05 \pm 1.20 \mathrm{mg}$ of SM, while the rest lipid classes were found in lower quantities. The principal lipid classes per $100 \mathrm{~g}$ of cephalothorax wet weight were $6112.35 \pm 43.99 \mathrm{mg}$ of TG, $1186.04 \pm 48.29 \mathrm{mg}$ of PC $193.46 \pm 9.90 \mathrm{mg}$ of $\mathrm{PE}$ and $119.53 \pm 2.98 \mathrm{mg}$ of cholesterol.

\begin{tabular}{|c|c|c|c|c|}
\hline \multirow{2}{*}{ Parameters } & \multicolumn{2}{|c|}{$A$. foliacea (red shrimp) } & P. longirostris (rose shrimp) \\
\cline { 2 - 5 } & Muscle & Cephalothorax & Muscle & Cephalothorax \\
\hline $\begin{array}{c}\text { Total weight } \\
\text { (\%w/w wet } \\
\text { tissue) }\end{array}$ & $46.08 \pm 0.44 \mathrm{a}$ & $52.75 \pm 0.88 \mathrm{~b}$ & $61.43 \pm 3.17 \mathrm{c}$ & $37.16 \pm 2.69 \mathrm{~d}$ \\
\hline Moisture & $78.97 \pm 1.46 \mathrm{a}$ & $72.80 \pm 1.84 \mathrm{~b}$ & $76.98 \pm 0.90 \mathrm{a}$ & $71.70 \pm 0.87 \mathrm{~b}$ \\
\hline Ash & $1.13 \pm 0.02 \mathrm{a}$ & $2.77 \pm 0.39 \mathrm{~b}$ & $2.39 \pm 0.32 \mathrm{~b}$ & $5.44 \pm 0.41 \mathrm{c}$ \\
\hline Protein & $17.75 \pm 0.11 \mathrm{a}$ & $9.69 \pm 0.29 \mathrm{~b}$ & $18.72 \pm 0.10 \mathrm{c}$ & $5.26 \pm 0.08 \mathrm{~d}$ \\
\hline Total lipids & $0.74 \pm 0.04 \mathrm{a}$ & $7.82 \pm 0.37 \mathrm{~b}$ & $1.04 \pm 0.14 \mathrm{c}$ & $4.66 \pm 0.35 \mathrm{~d}$ \\
\hline Results represent means $\pm \mathrm{SD}$ & $(\mathrm{n}=6$ separate samples). & \multicolumn{1}{l}{} \\
\hline
\end{tabular}

Means in the same row bearing different letters differ significantly $(P<0.05)$

Table 1: Total weight and proximate chemical composition (\% of wet tissue) of Aristaeomorpha foliacea and Penaeus longirostris muscle and cephalothorax.

\begin{tabular}{|c|c|c|c|c|}
\hline & \multicolumn{2}{|c|}{$A$. foliacea } & \multicolumn{2}{c|}{$\boldsymbol{P . ~ l o n g i r o s t i s}$} \\
\hline Lipids & Muscle & Cephalothorax & Muscle & Cephalothorax \\
\hline NL \% f TL & $12.58 \pm 0.77 a$ & $80.68 \pm 0.63 b$ & $11.85 \pm 0.53 a$ & $63.06 \pm 0.61 c$ \\
\hline Sterol esters & n.d & $0.32 \pm 0.03$ & n.d & n.d. \\
\hline TG & $3.30 \pm 0.23 a$ & $77.82 \pm 0.56 b$ & $3.35 \pm 0.22 a$ & $60.10 \pm 0.53 c$ \\
\hline FFA & $0.84 \pm 0.04 a$ & $0.49 \pm 0.04 b$ & n.d. & n.d. \\
\hline Cholesterol & $7.6 \pm 0.41 a$ & $1.53 \pm 0.05 b$ & $8.50 \pm 0.49 a$ & $2.96 \pm 0.16 c$ \\
\hline DG & $0.83 \pm 0.03 a$ & $0.52 \pm 0.03 b$ & n.d & n.d \\
\hline PL \% of TL & $87.42 \pm 0.77 a$ & $19.32 \pm 0.63 b$ & $88.15 \pm 0.53 a$ & $36.94 \pm 0.61 c$ \\
\hline PE & $19.04 \pm 0.45 a$ & $2.48 \pm 0.23 c$ & $17.13 \pm 0.35 b$ & $5.74 \pm 0.15 d$ \\
\hline PS & $2.39 \pm 0.04 a$ & $0.39 \pm 0.02 b$ & $2.94 \pm 0.03 a$ & $0.43 \pm 0.03 b$ \\
\hline PI & $1.57 \pm 0.03 a$ & $0.21 \pm 0.02 b$ & $1.40 \pm 0.05 c$ & $0.23 \pm 0.02 b$ \\
\hline PC & $61.16 \pm 0.69 a$ & $15.17 \pm 0.10 b$ & $63.17 \pm 0.49 c$ & $29.43 \pm 0.45 d$ \\
\hline SM & $3.26 \pm 0.13 a$ & $1.07 \pm 0.05 b$ & $3.51 \pm 0.15 a$ & $1.09 \pm 0.03 b$ \\
\hline
\end{tabular}

Results represent means \pm SD ( $n=6$ separate samples)

Means in the same row bearing different letters differ significantly $(P<0.05)$ TG: Triglycerides; FFA: Free Fatty Acids; DG: Diglycerides; MG: Monoglycerides; PE: Phospatidylethanolamine; PS: Phosphatidylserine; PC: Phosphatidylcholine SM: Sphingomyelin

n.d. $=$ not detected

Table 2: Neutral and polar lipid classes $\%(w / w)$ of total lipids of shrimps' muscle and cephalothorax. 
Parapenaeus longirostris' tissues showed similar results. Thus, 100 $\mathrm{g}$ of muscle contained $656.89 \pm 7.08 \mathrm{mg}$ of PC, $178.36 \pm 6.65 \mathrm{mg}$ of PE and $88.23 \pm 4.39 \mathrm{mg}$ of cholesterol, while the rest lipid classes were found in lower quantities. In the cephalothorax, TG were the most abundant lipid class with $2797.96 \pm 24.68 \mathrm{mg}$ per $100 \mathrm{~g}$ wet weight, followed by PC, PE and cholesterol (1373.06 $\pm 24.42,267.61 \pm 25.26$ and $139.39 \pm 27.13 \mathrm{mg}$ per $100 \mathrm{~g}$ wet weight, respectively).

From a nutritional point of view, cholesterol content in $A$. foliacea and $P$. longirostris varied from 56.12 to $88.23 \mathrm{mg}$ per $100 \mathrm{~g}$ in muscle respectively, which is contributory to a low cholesterol regime $(300$ $\mathrm{mg} /$ day for a man and $225 \mathrm{mg} /$ day for a woman). Our values for cholesterol in shrimp muscles were similar to those reported by Rosa and Nunes [17] for red shrimp (Aristeus antennatus) and Norway lobster (Nephrops norvegicus) (57.8-72.4 mg per $100 \mathrm{~g}$ wet tissue) and much lower than those reported by Turan et al. [15] for brown shrimp (Crangon crangon) (173.56 mg per $100 \mathrm{~g}$ wet tissue) and by Bragagnolo and Rodriguez-Amaya [20] for the wild marine shrimps (Penaeus brasiliensis, Penaeus schimitti, Xiphopenaeus kroyeri) (114-134 mg per $100 \mathrm{~g}$ wet tissue).

Choline was established as an essential nutrient with recommended daily intake (RDI) of $550 \mathrm{mg}$ for men and $450 \mathrm{mg}$ for women [21]. By estimating that phosphatidylcholine consists of approximately $13 \%$ choline by weight, the muscle and cephalothorax of $A$. foliacea and $P$. longirostris were found as an excellent source of dietary choline, providing $59-85 \mathrm{mg}$ and $154-178 \mathrm{mg}$ of choline per $100 \mathrm{~g}$ wet tissue, respectively. Furthermore, the particularly high levels of PC in the cephalothorax of the studied shrimps make them suitable source for industrial manufacture of lecithin.

\section{Fatty acids}

The fatty acid (FA) pattern of total lipids (TL) isolated from muscle and cephalothorax of the studied shrimps is shown in Table 3. The carbon chain length of the forty (40) identified fatty acids ranged from $10^{\circ} \mathrm{C}$ to $24^{\circ} \mathrm{C}$ and the number of double bonds ranged from 0 to 6 . The sums of FA for both shrimps muscles decreased according to the order PUFA $>$ SFA $>$ MUFA, while in the cephalothorax the order was MUFA $>$ SFA $>$ PUFA. The differentiation in individual FA proportions and sums of the examined shrimps was more pronounced in terms of the tissue (muscle and cephalothorax) than in terms of species. According to Ayas et al. (2013), the fatty acid composition of crustaceans is related to their life cycle and external factors, as temperature, water salinity, feed and season. The high level of unsaturated fatty acids for bathyal shrimp species may be explained due to the lower temperature of water at the deep seas [14].

Among the saturated fatty acids (SFA), palmitic (C16:0) and stearic (C18:0) acids were the most abundant in both shrimp muscle lipids, whereas palmitic (C16:0), stearic (C18:0) and arachidic (C20:0) acids predominated in cephalothorax lipids. Palmitic acid (C16:0) proportion was found to be more than the half of the total SFA proportion, in agreement to other researchers findings $[4,15,16]$. A significant difference $(P<0.05)$ in $\mathrm{C} 16: 0$ content was determined between $A$. foliacea and $P$. longirostris cephalothorax TL (1.33 instead of $0.70 \mathrm{~g}$ per $100 \mathrm{~g}$ wet tissue, respectively) (data calculated from Table 3 ).

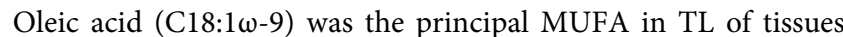
of both shrimps and its proportion was significantly higher in the cephalothorax than in the muscle TL. P. longirostris muscle TL had higher $(P<0.05) \mathrm{C} 18: 1 \omega-9$ content $(0.12 \mathrm{~g}$ per $100 \mathrm{~g}$ wet tissue $)$ than A. foliacea muscle $(0.10 \mathrm{~g}$ per $100 \mathrm{~g}$ wet tissue), although having lower proportion. Palmitoleic isomers $(\mathrm{C} 16: 1 \omega-7, \omega-9)$ and vaccenic

\begin{tabular}{|c|c|c|c|c|}
\hline \multirow{2}{*}{ Fatty acids } & \multicolumn{2}{|c|}{ A. foliacea } & \multicolumn{2}{|c|}{ P. longirostis } \\
\hline & Muscle & Cephalothorax & Muscle & Cephalothorax \\
\hline C10:0 & $0.36 \pm 0.00 a$ & $0.70 \pm 0.00 \mathrm{~b}$ & n.d. & $0.67 \pm 0.01 \mathrm{c}$ \\
\hline $\mathrm{C} 12: 0$ & n.d. & $0.13 \pm 0.00 a$ & n.d. & $0.14 \pm 0.00 b$ \\
\hline C14:0 & $1.18 \pm 0.02 a$ & $1.75 \pm 0.02 b$ & $1.25 \pm 0.00 c$ & $1.79 \pm 0.00 \mathrm{~cd}$ \\
\hline C14:1 & $0.07 \pm 0.00 a$ & $0.23 \pm 0.00 b$ & $0.16 \pm 0.00 c$ & $0.22 \pm 0.00 \mathrm{~d}$ \\
\hline C15:0 & $0.52 \pm 0.00 a$ & $0.56 \pm 0.00 b$ & $0.88 \pm 0.00 c$ & $0.57 \pm 0.00 \mathrm{bd}$ \\
\hline$C 15: 1 \omega-5$ & $0.07 \pm 0.00 a$ & $0.20 \pm 0.00 \mathrm{~b}$ & $0.29 \pm 0.00 c$ & $0.20 \pm 0.00 b$ \\
\hline C16:0 & $17.67 \pm 0.05 a$ & $20.23 \pm 0.06 b$ & $18.46 \pm 0.10 c$ & $18.65 \pm 0.11 d$ \\
\hline iso-C16:0 & $0.41 \pm 0.00 a$ & $0.83 \pm 0.01 b$ & $0.37 \pm 0.01 \mathrm{c}$ & $0.78 \pm 0.01 d$ \\
\hline $\begin{array}{c}C 16: 1 \omega-7 \\
\omega-9\end{array}$ & $4.03 \pm 0.01 a$ & $9.27 \pm 0.03 b$ & $4.13 \pm 0.01 c$ & $8.79 \pm 0.03 d$ \\
\hline iso-C17:0 & $0.81 \pm 0.01 a$ & $0.51 \pm 0.00 \mathrm{~b}$ & $1.26 \pm 0.01 \mathrm{c}$ & $0.47 \pm 0.01 d$ \\
\hline cyclo-C17:0 & $0.18 \pm 0.00 a$ & $0.20 \pm 0.00 b$ & $0.10 \pm 0.00 c$ & $0.47 \pm 0.01 d$ \\
\hline C17:0 & $0.92 \pm 0.01 a$ & $1.12 \pm 0.01 b$ & $1.13 \pm 0.01 b$ & $1.10 \pm 0.01 c$ \\
\hline $\mathrm{C} 17: 1 \omega-7$ & $0.28 \pm 0.00 a$ & $0.47 \pm 0.00 b$ & $0.50 \pm 0.01 \mathrm{c}$ & $0.30 \pm 0.01 d$ \\
\hline C18:0 & $5.74 \pm 0.06 a$ & $4.28 \pm 0.05 b$ & $5.25 \pm 0.06 c$ & $4.19 \pm 0.04 b$ \\
\hline C18:1trans-9 & $0.20 \pm 0.00 a$ & $0.18 \pm 0.00 b$ & $0.36 \pm 0.01 \mathrm{c}$ & $0.33 \pm 0.00 \mathrm{~d}$ \\
\hline C18:1w-9 & $18.46 \pm 0.18 a$ & $25.45 \pm 0.25 b$ & $15.75 \pm 0.16 c$ & $24.66 \pm 0.25 d$ \\
\hline C18:1w-7 & $3.42 \pm 0.02 a$ & $7.73 \pm 0.05 b$ & $5.03 \pm 0.03 c$ & $7.39 \pm 0.04 d$ \\
\hline $\begin{array}{l}\text { C18:2cis- } \\
\text { 9trans-11 }\end{array}$ & $0.24 \pm 0.00 a$ & $0.33 \pm 0.00 b$ & $0.66 \pm 0.01 c$ & $0.36 \pm 0.01 d$ \\
\hline C18:2w-6 & $1.31 \pm 0.01 a$ & $1.10 \pm 0.01 b$ & $1.36 \pm 0.01 c$ & $1.09 \pm 0.01 b$ \\
\hline C18:3w-6 & $0.32 \pm 0.00 a$ & $0.46 \pm 0.01 b$ & $0.49 \pm 0.01 \mathrm{c}$ & $0.91 \pm 0.01 d$ \\
\hline C18:3w-3 & $0.49 \pm 0.01 a$ & $0.92 \pm 0.01 b$ & $0.39 \pm 0.00 c$ & $0.55 \pm 0.01 d$ \\
\hline C18:4w-3 & $0.21 \pm 0.00 a$ & $0.29 \pm 0.00 b$ & $0.18 \pm 0.00 c$ & $0.22 \pm 0.00 \mathrm{~d}$ \\
\hline C19:0 & $0.17 \pm 0.00 a$ & $0.50 \pm 0.00 b$ & $0.69 \pm 0.01 c$ & $1.11 \pm 0.01 d$ \\
\hline C20:0 & $2.32 \pm 0.03 a$ & $4.90 \pm 0.07 b$ & $2.74 \pm 0.04 c$ & $5.38 \pm 0.08 d$ \\
\hline$C 20: 1 \omega-9$ & $0.34 \pm 0.00 a$ & $1.02 \pm 0.02 b$ & $0.65 \pm 0.01 c$ & $1.17 \pm 0.02 d$ \\
\hline$C 20: 2 \omega-6$ & $0.56 \pm 0.01 a$ & $0.53 \pm 0.01 b$ & $0.88 \pm 0.01 \mathrm{c}$ & $0.58 \pm 0.01 a$ \\
\hline $\mathrm{C} 20: 3 \omega-6$ & $0.08 \pm 0.00 a$ & $0.78 \pm 0.01 b$ & $0.17 \pm 0.00 c$ & $0.17 \pm 0.00 c$ \\
\hline$C 20: 4 \omega-6$ & $4.75 \pm 0.09 a$ & $2.25 \pm 0.04 b$ & $5.56 \pm 0.10 c$ & $2.73 \pm 0.05 d$ \\
\hline$C 20: 3 \omega-3$ & $0.26 \pm 0.01 a$ & $0.45 \pm 0.01 b$ & $0.18 \pm 0.00 c$ & $0.28 \pm 0.00 \mathrm{~d}$ \\
\hline$C 20: 5 \omega-3$ & $12.82 \pm 0.18 a$ & $3.76 \pm 0.05 b$ & $12.68 \pm 0.18 a$ & $4.00 \pm 0.06 c$ \\
\hline C22:0 & $0.25 \pm 0.01 a$ & $0.13 \pm 0.00 b$ & $0.61 \pm 0.01 \mathrm{c}$ & $0.16 \pm 0.00 d$ \\
\hline $\mathrm{C} 22: 1 \omega-11$ & $0.67 \pm 0.01 a$ & $0.21 \pm 0.00 b$ & $0.14 \pm 0.00 c$ & $0.30 \pm 0.01 d$ \\
\hline $\mathrm{C} 22: 1 \omega-9$ & $0.23 \pm 0.00 a$ & $0.19 \pm 0.00 b$ & $0.09 \pm 0.00 c$ & $0.23 \pm 0.00 \mathrm{~d}$ \\
\hline $\mathrm{C} 22: 2 \omega-6$ & $0.10 \pm 0.00 a$ & $0.14 \pm 0.00 b$ & $0.11 \pm 0.00 c$ & $0.08 \pm 0.00 d$ \\
\hline $\mathrm{C} 22: 4 \omega-6$ & n.d. & $1.20 \pm 0.01 a$ & $0.49 \pm 0.00 b$ & $1.50 \pm 0.01 \mathrm{c}$ \\
\hline $\mathrm{C} 22: 5 \omega-6$ & $0.32 \pm 0.00 a$ & $0.56 \pm 0.00 b$ & $0.64 \pm 0.01 \mathrm{c}$ & $0.63 \pm 0.01 c$ \\
\hline $\mathrm{C} 22: 5 \omega-3$ & $0.66 \pm 0.00 a$ & n.d. & $0.55 \pm 0.00 b$ & $0.63 \pm 0.01 \mathrm{c}$ \\
\hline C24:0 & $0.62 \pm 0.01 a$ & $0.46 \pm 0.01 b$ & $1.39 \pm 0.03 c$ & $0.59 \pm 0.01 d$ \\
\hline $\mathrm{C} 22: 6 \omega-3$ & $18.62 \pm 0.34 a$ & $5.71 \pm 0.10 b$ & $14.28 \pm 0.26 c$ & $6.28 \pm 0.11 d$ \\
\hline $\mathrm{C} 24: 1 \omega-9$ & $0.34 \pm 0.01 a$ & $0.27 \pm 0.01 b$ & $0.15 \pm 0.00 c$ & $0.35 \pm 0.01 a$ \\
\hline$\Sigma \omega: 0$ (SFA) & $31.15 \pm 0.18 a$ & $36.30 \pm 0.22 b$ & $34.13 \pm 0.22 c$ & $36.07 \pm 0.22 b$ \\
\hline$\Sigma \omega: 1$ (MUFA) & $28.11 \pm 0.25 a$ & $45.22 \pm 0.36 b$ & $27.25 \pm 0.23 c$ & $43.92 \pm 0.35 d$ \\
\hline$\Sigma \omega: n$ (PUFA) & $40.74 \pm 0.65 a$ & $18.48 \pm 0.26 b$ & $38.62 \pm 0.59 c$ & $20.00 \pm 0.28 d$ \\
\hline$\Sigma \omega: 3$ & $33.06 \pm 0.53 a$ & $11.13 \pm 0.17 b$ & $28.25 \pm 0.45 c$ & $11.95 \pm 0.18 d$ \\
\hline$\Sigma \omega: 6$ & $7.44 \pm 0.12 a$ & $7.03 \pm 0.09 b$ & $9.71 \pm 0.15 c$ & $7.69 \pm 0.10 d$ \\
\hline$\omega-3 / \omega-6$ & $4.44 \pm 0.01 a$ & $1.58 \pm 0.01 b$ & $2.91 \pm 0.01 \mathrm{c}$ & $1.55 \pm 0.01 b$ \\
\hline MUFA/SFA & $0.90 \pm 0.01 a$ & $1.25 \pm 0.01 b$ & $0.80 \pm 0.01 c$ & $1.22 \pm 0.01 d$ \\
\hline PUFA/SFA & $1.31 \pm 0.01 \mathrm{a}$ & $0.51 \pm 0.01 b$ & $1.13 \pm 0.01 \mathrm{c}$ & $0.55 \pm 0.04 b$ \\
\hline TFA $^{*}$ & 0.56 & 6.57 & 0.79 & 3.73 \\
\hline SFA* & 0.17 & 2.38 & 0.27 & 1.35 \\
\hline MUFA $^{*}$ & 0.16 & 2.97 & 0.22 & 1.63 \\
\hline PUFA* & 0.23 & 1.22 & 0.30 & 0.75 \\
\hline$\Sigma \omega: 3^{*}$ & 0.19 & 0.73 & 0.22 & 0.45 \\
\hline$\Sigma \omega: 6^{*}$ & 0.04 & 0.46 & 0.08 & 0.29 \\
\hline \multicolumn{5}{|c|}{$\begin{array}{l}\text { Results represent means } \pm \text { SD }(n=6 \text { separate samples }) \\
\text { Means in the same row bearing different letters differ significantly }(P<0.05) \text {. } \\
\text { *Expressed as } g \text { per } 100 \mathrm{~g} \text { wet tissue. } \\
\text { SFA: Saturated Fatty Acids; MUFA: Monounsaturated Fatty Acids; PL }\end{array}$} \\
\hline
\end{tabular}

Table 3: Fatty acid composition \% (w/w) of TFA in total lipids of $A$. foliacea and $P$. longirostris muscle and cephalothorax. 
(C18:1 $\omega-7)$ acids were the second most abundant MUFA in muscle and cephalothorax TL of the studied shrimps and their proportions were found almost double in cephalothorax than in muscle TL.

Eicosapentaenoic (C20:5 $\omega-3, \mathrm{EPA})$ and docosahexaenoic (C22:6 $\omega-3$, DHA) acids were the dominant PUFA in lipid of both shrimps muscle and cephalothorax, followed by arachidonic acid (C20:4 $\omega-6)$. The contents of both shrimp muscle and cephalothorax TL in DHA were almost 1.3-fold higher than those of EPA (data calculated from Table 3).

All the principal FA mentioned above have also been reported as main FA in several shrimp species $[13,15,18,22,23]$. It is important to point out the identification of the C18:1trans-9 (elaidic acid) as well as of the conjugated linoleic acid (CLA) isomer, C18:2cis-9trans11(rumenic acid).

The $\omega-3 / \omega-6$ ratio was found significantly higher in both shrimp muscle TL than the respective in cephalothorax TL, presenting the highest value in $A$. foliacea muscle (Table 3 ). The PUFA/SFA ratios are beneficial, as their values were higher to the recommended value of 0.45 [24] in all samples. Furthermore, the PUFA/SFA ratio of both shrimps muscle TL was 2-2.6 times higher than the respective one of the cephalothorax.

According to Dayal et al. [25], dieticians and consumers are sceptical about considering shrimp as a healthy food due to its relatively high cholesterol content. Therefore, lipid quality indices' calculation is of value, to pinpoint the cholesterolaemic effect of shrimp lipids. According to the results of this study (Table 4), the atherogenic (AI) and the thrombogenic (TI) indices of shrimp muscle TL were found 0.33-0.36 and 0.20-0.24, respectively, corresponding in much lower values compared to foods of animal origin [24,26]. The high hypocholesterolaemic/hypercholesterolaemic $(\mathrm{h} / \mathrm{H})$ ratio and the low values of cholesterol (CI) and cholesterol-saturated fat (CSI) indices of shrimp muscle TL indicate their protective nature against heart disease risk.

The amounts of PUFA provided by $100 \mathrm{~g}$ of cephalothorax are higher than those given by the same quantity of muscle, despite their lower relative percentages, related to cephalothorax higher total lipid content (Table 3). Thus, $100 \mathrm{~g}$ of $A$. foliacea and P. longirostris cephalothorax provide 1.22 and $0.75 \mathrm{~g}$ PUFA as well as 0.73 and 0.45 $\omega-3$ fatty acids, respectively, encouraging the full exploitation of this by-product as an exceptional source of essential fatty acids.

\section{Carotenoid composition}

HPLC-DAD analysis of carotenoids revealed the presence of seven carotenoid molecular species (Table 5). The comparison among the muscle and cephalothorax carotenoids in both shrimps showed that free astaxanthin predominated in both tissues, followed by lutein. Furthermore, lesser amounts of zeaxanthin, canthaxanthin, $\alpha$ - and $\beta$-cryptoxanthin and unidentified astaxanthin esters were determined in all tissues. The last-mentioned compounds showed similar absorption spectra with trans-astaxanthin, demonstrating astaxanthinderived compounds like astaxanthin esters [12]. Crustaceans, such as shrimps, contain astaxanthin as their main pigment, which is mainly formed from beta-carotene or zeaxanthin via the oxidative conversion $[27,28]$.

From a nutritional point of view, the amount of total carotenoids in A. foliacea muscle and cephalothorax TL was found almost double than the respective amount in P. longirostis tissues TL (Table 5), possibly related to their coloration. Moreover, it is estimated that 100 $\mathrm{g}$ of $A$. foliacea muscle provides $1.56 \mathrm{mg}$ of astaxanthin and $1.07 \mathrm{mg}$ of lutein instead of $0.73 \mathrm{mg}$ of astaxanthin and $0.47 \mathrm{mg}$ of lutein for $P$. longirostis muscle TL (data calculated from Table 5). High levels of astaxanthin in cephalothorax make them an excellent natural source of this carotenoid. Astaxanthin obtained from shrimp waste can be used as coloring additive in foods or aquaculture feed formulations, in medical and biomedical applications or as a natural supplement in human nutrition [29]. The demand for natural sources of astaxanthin is growing because it is stable, harmless for human health as it doesn't cause allergic reactions in contrast to its synthetic form, so it is suitable for cosmetic applications [30]. Therefore, many studies have been conducted to extract astaxanthin from shrimp waste using various methods [29]. Astaxanthin and its esterified forms, canthaxanthin, free and esterified form of lutein, zeaxanthin and b-carotene are reported as the major pigments in various shrimp species (Crangon crangon, Solonocera indica, Aristeus alcocki, Penaeus monodon, Penaeus indicus, Metapenaeus dobsonii and Parapenaeopsis stylifera) [14,27]. As reported by Manjabhat et al. [14] and Sachindra et al. [27], the presence and the percentage of carotenoids in shrimp components are closely linked to their natural environment or provided food, because shrimps obtain carotenoids from their food, not being able to synthesize them de novo. The geographical position is also an important factor for the quantitative and qualitative profile of shrimp's carotenoids $[31,32]$. For instance, deep-shrimp species, similar to the the ones studied, contain higher amounts of total carotenoids than those in shallow waters, so they exhibit more intense color [19].

\begin{tabular}{|c|c|c|c|c|}
\hline \multirow{2}{*}{ Indices } & \multicolumn{2}{|c|}{$A$. foliacea } & \multicolumn{2}{c|}{$\boldsymbol{P}$. longirostis } \\
\cline { 2 - 5 } & Muscle & Cephalothorax & Muscle & Cephalothorax \\
\hline $\mathrm{Al}$ & $0.33 \pm 0.01 \mathrm{a}$ & $0.43 \pm 0.02 \mathrm{~b}$ & $0.36 \pm 0.01 \mathrm{a}$ & $0.41 \pm 0.02 \mathrm{~b}$ \\
\hline $\mathrm{TI}$ & $0.20 \pm 0.00 \mathrm{a}$ & $0.43 \pm 0.02 \mathrm{~b}$ & $0.24 \pm 0.01 \mathrm{c}$ & $0.39 \pm 0.01 \mathrm{~d}$ \\
\hline $\mathrm{h}$ & $57.11 \pm 0.36 \mathrm{a}$ & $39.19 \pm 0.42 \mathrm{~b}$ & $50.57 \pm 0.57 \mathrm{c}$ & $39.94 \pm 0.48 \mathrm{~b}$ \\
\hline $\mathrm{H}$ & $18.85 \pm 0.17 \mathrm{a}$ & $21.98 \pm 0.26 \mathrm{~b}$ & $19.71 \pm 0.19 \mathrm{c}$ & $20.44 \pm 0.24 \mathrm{~d}$ \\
\hline $\mathrm{h} / \mathrm{H}$ & $3.03 \pm 0.02 \mathrm{a}$ & $1.78 \pm 0.03 \mathrm{~b}$ & $2.57 \pm 0.02 \mathrm{c}$ & $1.95 \pm 0.01 \mathrm{~d}$ \\
\hline $\mathrm{Cl}$ & $3.42 \pm 0.07 \mathrm{a}$ & $8.96 \pm 0.09 \mathrm{~b}$ & $5.42 \pm 0.14 \mathrm{c}$ & $9.35 \pm 0.21 \mathrm{~d}$ \\
\hline $\mathrm{CSI}$ & $2.98 \pm 0.05 \mathrm{a}$ & $8.38 \pm 0.16 \mathrm{~b}$ & $4.68 \pm 0.10 \mathrm{c}$ & $8.33 \pm 0.11 \mathrm{~b}$ \\
\hline
\end{tabular}

Results represent means \pm SD ( $n=6$ separate samples).

Means in the same row bearing different letters differ significantly $(P<0.05)$

Table 4: Atherogenic (Al), thrombogenic (TI), hypocholesterolaemic and hypercholesterolaemic fatty acids $(\mathrm{h} / \mathrm{H})$, cholesterol $(\mathrm{Cl})$ and cholesterol-saturated fat (CSI) indices in total lipids of $A$. foliacea and $P$. longirostris muscle and cephalothorax.

\begin{tabular}{|c|c|c|c|c|}
\hline \multirow{2}{*}{ Carotenoids } & \multicolumn{2}{|c|}{ A. foliacea } & \multicolumn{2}{|c|}{ P. longirostis } \\
\hline & Muscle & Cephalothorax & Muscle & Cephalothorax \\
\hline Astaxanthin & $34.73 \pm 0.87 a$ & $37.55 \pm 0.64 b$ & $34.32 \pm 0.58 a$ & $49.08 \pm 0.82 c$ \\
\hline Zeaxanthin & $9.55 \pm 0.12 a$ & $16.48 \pm 0.26 b$ & $10.39 \pm 0.32 c$ & $11.82 \pm 0.27 d$ \\
\hline Canthaxanthin & $10.34 \pm 0.29 a$ & $8.23 \pm 0.16 b$ & $12.31 \pm 0.43 c$ & $7.68 \pm 0.26 d$ \\
\hline Lutein & $23.84 \pm 0.54 a$ & $29.59 \pm 0.69 b$ & $22.12 \pm 0.42 c$ & $18.64 \pm 0.37 d$ \\
\hline $\begin{array}{l}\text { Unidentified } \\
\text { Astaxanthin } \\
\text { esters }\end{array}$ & $16.24 \pm 0.39 a$ & $7.15 \pm 0.22 b$ & $12.25 \pm 0.17 \mathrm{c}$ & $9.58 \pm 0.24 d$ \\
\hline$\alpha$-cryptoxanthin & $3.20 \pm 0.11 a$ & $0.65 \pm 0.06 b$ & $4.53 \pm 0.14 c$ & $1.67 \pm 0.08 d$ \\
\hline$\beta$-cryptoxanthin & $2.10 \pm 0.05 a$ & $0.35 \pm 0.04 b$ & $4.08 \pm 0.12 c$ & $1.53 \pm 0.09 d$ \\
\hline $\begin{array}{l}\text { Total } \\
\text { carotenoids } \\
\text { mg/100 g wet } \\
\text { tissue }\end{array}$ & $4.49 \pm 0.09 a$ & $28.24 \pm 0.67 b$ & $2.12 \pm 0.06 c$ & $10.08 \pm 0.23 d$ \\
\hline
\end{tabular}

Results represent means $\pm S D$ ( $n=6$ separate samples).

Means in the same row bearing different letters differ significantly $(P<0.05)$.

Table 5: Carotenoid composition (\% (w/w) of total carotenoids) of shrimps' muscle and cephalothorax. 


\section{Conclusion}

The shrimps Aristaeomorpha foliacea and Parapenaeus longirostris are typically and commercially exploited fisheries of the Mediterranean Sea. The nutritional value of shrimp muscles proved to be highly important due to the presence of bioactive lipid constituents, namely choline, astaxanthin and $\omega-3$ fatty acids, beneficial to human health. Results from the present study confirm why red shrimps occupy a prominent position in the Mediterranean diet. Moreover, the recovered bioactive lipid molecules from shrimp cephalothorax, currently available in massive amounts as industrial bio-waste, can be used to produce functional supplements.

\section{References}

1. Larsen R, Eilertsen KE, Elvevoll EO (2011) Health benefits of marine foods and ingredients. Biotechnol Adv 29: 508-518.

2. Carpenter KE, De Angelis N (2014) The living marine resources of the Eastern Central Atlantic. Volume 1: Introduction, crustaceans, chitons, and cephalopods. FAO Species Identification Guide for Fishery Purposes, Rome, FAO.

3. Kapiris K (2012) Feeding habits of both deep-water red shrimps, Aristaeomorpha foliacea and Aristeus antennatus (Decapoda, Aristeidae) in the lonian Sea (E. Mediterranean), in agricultural and biological sciences "food quality" book. K. Kapiris (ed.) INTECH Open Access Publisher.

4. Yerlikaya P, Topuz OK, Buyukbenli HA, Gokoglu N (2013) Fatty acid profiles of different shrimp species: Effects of depth of catching. J Aquat Food Prod T 22: $290-297$.

5. AOAC (2000) Official methods of analysis. Washington, DC: Association of Official Analytical Chemists.

6. Bligh ED, Dyer WJ (1959) A rapid method of total lipid extraction and purification. Can J Biochem Physiol 37: 911-917.

7. Sinanoglou VJ, Strati IF, Bratakos SM, Proestos C, Zoumpoulakis P, et al. (2013) On the combined application of latroscan-TLC-FID and GC-FID to identify total, neutral and polar lipids and their fatty acids extracted from foods. ISRN Chromatography 2013: 8.

8. Santos-Silva J, Bessa RJB, Santos-Silva F (2002) Effect of genotype, feeding system and slaughter weight on the quality of light lambs. II. Fatty acid composition of meat. Livest Prod Sci 77: 187-194.

9. Ulbrich TLV, Southgate DAT (1991) Coronary heart disease seven dietary factors. Lancet 338: 985-992.

10. Zilversmit DB (1979) Cholesterol index of foods. Teaching tool for fat-modified diets. J Am Diet Assoc 74: 562-565.

11. Connor SL, Gustafson JR, Artaud-Wild SM, Favell DP, Classick-Kohn CJ, et al. (1986) The cholesterol/saturated-fat index an indication of the hypercholesterolemic and atherogenic potential of food. Lancet 327: 12291232.

12. Strati IF, Sinanoglou VJ, Kora L, Miniadis-Meimaroglou S, Oreopoulou V (2012) Carotenoids from foods of plant, animal and marine origin: An efficient HPLC-DAD separation method. Foods 1: 52-65.

13. Tsape K, Sinanoglou VJ, Miniadis-Meimaroglou S (2010) Comparative analysis of the fatty acid and sterol profiles of widely consumed Mediterranean crustacean species. Food Chem 122: 292-299.

14. Manjabhat SN, Narayan B, Subbanna MN (2006) Carotenoids in Solonocera indica and Aristeus alcocki, deep-sea shrimp from Indian waters. J Aquat Food Prod T 15: 5-16.

15. Turan H, Kaya Y, Erdem ME (2011) Proximate composition, cholesterol, and fatty acid content of brown shrimp (Crangon crangon L. 1758) from Sinop region, Black Sea. J Aquat Food Prod T 20: 100-107.
16. Li G, Sinclair AJ, Li D (2011) Comparison of lipid content and fatty acid composition in the edible meat of wild and cultured freshwater and marine fish and shrimps from China. J Agric Food Chem 59: 1871-1881.

17. Rosa R, Nunes ML (2003) Nutritional quality of red shrimp, Aristeus antennatus (Risso), pink shrimp, Parapenaeus longirostris (Lucas), and Norway lobster Nephrops norvegicus (Linnaeus). J Sci Food Agr 84: 89-94.

18. Sriket P, Benjakul S, Visessanguan W, Kijroongrojana K (2007) Comparative studies on chemical composition and thermal properties of black tiger shrimp (Penaeus monodon) and white shrimp (Penaeus vannamei) meats. Food Chem 103: 1199-1207

19. Allen CE (1998) Lipid profiles of deep-sea organisms. PhD Thesis. University of Southampton. School of ocean and earth science. United Kingdom of England.

20. Bragagnolo N, Rodriguez-Amaya DB (2001) Total lipid, cholesterol, and fatty acids of farmed freshwater prawn (Macrobrachium rosenbergii) and wild marine shrimp (Penaeus brasiliensis, Penaeus schimitti, Xiphopenaeus kroyeri). J Food Compos Anal 14: 359-369.

21. McNamara DJ, Thesmar HS (2005) Eggs. Egg Nutrition Center, Washington, DC, USA.

22. Ayas D, Ozogul Y, Yazgan $H$ (2013) The effects of season on fat and fatty acids contents of shrimp and prawn species. Eur J Lipid Sci Tech 115: 356-362.

23. Miniadis-Meimaroglou S, Kora L, Sinanoglou VJ (2008) Isolation and identification of phospholipid molecular species in a wild marine shrimp Penaeus kerathurus muscle and cephalothorax. Chem Phys Lipids 152: 104-112.

24. Sinanoglou VJ, Strati IF, Miniadis-Meimaroglou S (2011) Lipid, fatty acid and carotenoid content of edible egg yolks from avian species: A comparative study. Food Chem 124: 971-977.

25. Dayal JS, Ponniah AG, Khan HI, Babu EPM, Ambasankar K, et al. (2013) Shrimps - A nutritional perspective. Curr Sci 104: 1487-1491.

26. Sinanoglou VJ, Koutsouli P, Fotakis C, Sotiropoulou G, Cavouras D, et al. (2015) Assessment of lactation stage and breed effect on sheep milk fatty acids' profile and lipid quality indices. Dairy Sci Technol 95: 509-531.

27. Sachindra NM, Bhaskar N, Mahendrakar NS (2005) Carotenoids in different body components of Indian shrimps. J Sci Food Agr 85: 167-172.

28. Armenta R, Guerrero-Legarreta I (2009) Amino acid profile and enhancement of the enzymatic hydrolysis of fermented shrimp carotenoproteins. Food Chem 112: $310-315$

29. Kandra P, Challa MM, Jyothi HKP (2012) Efficient use of shrimp waste: Present and future trends. Appl Microbiol Biotechnol 93: 17-29.

30. Franco-Zavaleta ME, Jiménez-Pichardo R, Tomasini-Campocosio A, GuerreroLegarreta I (2010) Astaxanthin extraction from shrimp wastes and its stability in 2 model systems. J Food Sci 75: 394-399.

31. Yanar Y, Çelik M, Yanar M (2004) Seasonal changes in total carotenoid of wild marine shrimps (Penaeus semisulcatus and Metapenaeus monoceros) inhabiting the eastern Mediterranean. Food Chem 88: 267-269.

32. Sánchez-Camargo AP, Almeida MMA, Lopes BLF, Cabral FA (2011) Proximate composition and extraction of carotenoids and lipids from Brazilian red-spotted shrimp waste (Farfantepenaeus paulensis). J Food Eng 102: 87-93. 